\title{
The Effect of Cathode Materials on Indirect Electrochemical Oxidation of Methyl Orange, Malachite Green and Methylene Blue
}

\author{
Anantha N.S. Rao, Venkatesha T. Venkatarangaiah* \\ ${ }^{a}$ Department of P.G. studies and Research in Chemistry, School of Chemical Sciences, \\ Kuvempu University, Shankaraghatta-577451, Karnataka, India
}

Received 7 May 2014; accepted 23 June 2014

\begin{abstract}
The influence of cathode material on the electrochemical degradation of methyl orange (MO), methylene blue (MB) and malachite green (MG) dyes was investigated. The cathode materials used were platinum $(\mathrm{Pt})$, copper $(\mathrm{Cu})$, zinc $(\mathrm{Zn})$ and aluminum $(\mathrm{Al})$. The electrochemical activity of the selected dyes on the metal cathodes was examined by cyclic voltammetry $(\mathrm{CV})$. The electrochemical treatment was carried out in both divided and undivided cells. The degradation process was monitored by UV-Visible spectroscopy and chemical oxygen demand (COD) measurement. The influence of $\mathrm{pH}$ on discoloration and degradation of dyes was studied. The power consumption and current efficiency of the treatment process involving different cathode materials was computed and compared. The role of cathode material in the degradation of dyes has been established.
\end{abstract}

Keywords: Malachite green; Methylene blue; Methyl orange; Discoloration; Degradation.

\section{Introduction}

Dyes are the major constituents of textile industrial effluents. They impart intense color to water. Most of them are highly toxic to aquatic life and also to human beings. The methylene blue (MB), malachite green (MG) and methyl orange (MO) dyes are used on large scale in dying industries (Table 1). The MG is a cationic water soluble dye used in textile industries for coloring nylon, wool, silk, leather, cotton and jute [1-5]. Also, it finds application as antifungal, antibacterial and anti-parasitical agent in agriculture, fish hatchery and animal husbandry $[1,3,5,6]$. In anaerobic conditions, the bacteria commonly present in

\footnotetext{
* Corresponding author. E-mail address: drtvvenkatesha@yahoo.co.uk
} 
mammalian intestine convert malachite green into toxic colorless leucomalachite green, which poses carcinogenic, mutagenic and teratogenic effects on aquatic life [1, 4, 7]. The degradation products of malachite green are also carcinogenic. Intervention of these species into the food chain is lethal. Another dye, methylene blue, a chlorinated polycyclic synthetic organic compound, has structural similarity with rhodamine $b$, naphthol blue black and acid orange 7 [8]. MB is a widely used dye in dying cotton, wool, acrylic and silk [9, 10, 11]. It is highly stable and antibiodegradable [11]. Its consumption causes nausea, diarrhea, burning of eyes, vomiting, breathing difficulty, mental disorder, sweating $[9,10]$. Methyl orange represents the azo dye family and is commonly used in the titrations of mid strength acids. MO has not shown any harmful effects on rats when used in limited oral and injection range. However, a high acute oral toxicity was noticed [12].

Table 1. Structure and properties of dyes used in this study.

\begin{tabular}{|c|c|c|c|}
\hline Dye & Methyl Orange & Malachite Green & Methylene Blue \\
\hline Structure & & & \\
\hline Properties & $\begin{array}{l}\text { Anionic azo dye } \\
{ }^{\mathrm{a}} \lambda_{\max }-465 \mathrm{~nm} \\
{ }^{\mathrm{b}} \mathrm{CI}-13025\end{array}$ & $\begin{array}{l}\text { Cationic triphenylmethane dye } \\
\lambda_{\max }-617 \mathrm{~nm} \\
\text { CI }-42000\end{array}$ & $\begin{array}{l}\text { Cationic heterocyclic dye } \\
\lambda_{\max }-661 \mathrm{~nm} \\
\text { CI }-52015\end{array}$ \\
\hline
\end{tabular}

Various methods are used to treat the wastewater containing organic dyes. Physical (precipitation, adsorption) [1, 5, 13-16] chemical [10]; biological [2, 6, 17, 18], photocatalytic [19, 20, 21, 22, 23]; electro-oxidation [4, 9, 24-26]; electro-reduction [27, 28, 29]; photoelectrochemical [30, 31, 32]; electro-Fenton $[33,34,35]$ are amongst the most recognized methods.

The electrochemical oxidation method has attracted a large group of researchers in the past three decades. In this method, the efficiency of decontamination of wastewater is dependent on the nature of the electrode. The incineration of organics into $\mathrm{CO}_{2}$ and $\mathrm{H}_{2} \mathrm{O}$ is possible only by the oxidation reaction. The electrochemical oxidation process is therefore widely appreciated and extensive research on the fabrication of anode material with excellent catalytic activity for the oxidation of organics (direct oxidation) and generation of oxidants (indirect oxidation) is underway.

Nevertheless, the cathode material and reaction at cathode also influence the oxidation of organics. The cathode material can indirectly aid the organic removal by:

- electro-reduction of dissolved oxygen into $\mathrm{H}_{2} \mathrm{O}_{2}$, which is an oxidizing agent;

- direct electro-reduction of organics into compounds susceptible to oxidation;

- generating coagulants for the adsorption of organics;

- direct adsorption of organics (porous carbonaceous cathodes). 
The halogenated hydrocarbons like, $\mathrm{CHCl}_{3}$, chlorofluorocarbons (CFCs), chlorobenzene, chlorophenols, hexachlorocyclohexane are effectively dehalogenated by electrochemical reduction [33]. The dyes with $-\mathrm{SO}_{3}^{-}, \mathrm{COO}^{-}$, $\mathrm{SO}_{2} \mathrm{NH}_{2},-\mathrm{OH}$, hydrophilic groups, and azo linkages are susceptible to electroreduction [36]. Uniform reduction of organics takes place followed by adsorption of intermediates on ACF cathode [36-38]. These reactions taking place in the vicinity of the cathode should be co-operative with the anodic reactions in order to achieve efficient organic removal. It has been reported that the degradation of 2-chlorophenol and 2, 4-dichlorophenol using carbon/polytetrafluoroethylene (C/PTFE) $\mathrm{O}_{2}$-fed as cathode and $\mathrm{Ti} / \mathrm{IrO}_{2} / \mathrm{RuO}_{2}$ as anode was cooperative oxidation. The degradation was achieved by direct and indirect electrochemical oxidation by $\mathrm{H}_{2} \mathrm{O}_{2}$ and $\mathrm{HO}^{\circ}$ produced by oxygen reduction at the cathode [39].

$\mathrm{Ag}, \mathrm{Al}, \mathrm{Au}, \mathrm{Cu}, \mathrm{Ni}, \mathrm{Pb}, \mathrm{Pd}, \mathrm{Pt}, \mathrm{Ti}, \mathrm{Zn}$, graphite, glassy carbon, activated carbon fiber (ACF) have been used as cathode materials in the electrochemical treatment of wastewater containing different organic dyes [36-38]. However, only few research teams have tried to analyze the effect of cathode material on the organic removal efficiency [40]. Studies on the co-operation between electrochemical oxidation and reduction reactions in the degradation of aqueous dyes are rarely found in the literature. Also, the contribution of cathode material to the degradation of organics has not been studied. In this paper, we investigate the effect of cathode material and cathodic reactions using different metal cathodes by evaluating the changes in color and COD of the aqueous synthetic dye solutions.

\section{Materials and chemicals \\ Chemicals}

Commercially available malachite green (MG), methylene blue (MB) and methyl orange (MO) dyes (S. D. Fine Chemicals Ltd., India) were used for the studies as received. Millipore water (specific resistance $>18 \mathrm{M} \Omega$ at $25^{\circ} \mathrm{C}$, Millipore Elix 3 water purification system, France) was used to prepare the dye solutions and $\mathrm{NaCl}$ was used as supporting electrolyte [analytical grade $\mathrm{NaCl}(0.2 \%(w / v), 2 \mathrm{~g}$ $\mathrm{L}^{-1}$ ) and $50 \mathrm{mg} \mathrm{L}^{-1}$ dye]. The $\mathrm{Zn}, \mathrm{Cu}, \mathrm{Al}$ metal foils (99.99\%) purchased from Sisco research laboratories, Mumbai, India, and Pt foils supplied by Systronics India Ltd. Bangalore, India, were used. The dil. $\mathrm{HNO}_{3}(10 \%)$, dil. $\mathrm{HCl}(10 \%)$ and $\mathrm{NaOH}(40 \%)$ (HiMedia Laboratories Pvt. Ltd, Bangalore, India) were used for the pretreatment of electrodes. The dialysis membrane-70 with relative pore size of $0.1 \mu \mathrm{m}$ (HIMEDIA) was used in the divided cell experiments.

\section{Experimental}

The electrolysis experiments were performed under galvanostatic condition and the current was drawn from a DC power supply (model PS 618 potentiostat/galvanostat 302/2 A supplied by Chem link, Mumbai). All experiments were carried out at ambient temperature. The electrolysis of dye solution was carried out in both single compartment and two-compartment cells 
under the current density of $40 \mathrm{~mA} \mathrm{~cm}^{-2}$ to know the contributions of cathodic and anodic reactions. A volume of $50 \mathrm{~cm}^{3}$ of dye test solution was used in the undivided cell and in each compartment of the divided cell. Pretreated metal foils $\left(\mathrm{Al}, \mathrm{Cu}, \mathrm{Zn}\right.$ and $\mathrm{Pt}$ ) with exposed surface area of $0.5 \mathrm{~cm}^{2}$ were used as cathode and $\mathrm{Pt}\left(0.54 \mathrm{~cm}^{2}\right)$ as anode in all the experiments. Prior to the experiments, the Al foil was dipped in $40 \% \mathrm{NaOH}, \mathrm{Cu}$ in $10 \% \mathrm{HNO}_{3}$ and $\mathrm{Zn}$ in $10 \% \mathrm{HCl}$, for 1 min, washed thoroughly with Millipore water, abraded with series of emery papers of grade number 660 and 1200 followed by washing in Millipore water. Pt foil was dipped in $10 \% \mathrm{HNO}_{3}$ and sonicated for 1 min and thoroughly washed with Millipore water. The working electrode potential was recorded with respect to the saturated calomel electrode (SCE). The electrolysis was performed for 60 minutes under stirring using magnetic bar $(550 \mathrm{rpm})$ to achieve proper mixing and reproducible mass transport onto the electrode surface. The samples were collected at appropriate time intervals to monitor the color and COD change.

\section{Analysis}

\section{Electrochemical measurements}

The electrochemical behavior of dyes on the cathode surface was evaluated by $\mathrm{CV}$ and the potential for hydrogen evolution on different metal cathodes was determined by linear sweep voltammetry (LSV) in $0.2 \% \mathrm{NaCl}(\mathrm{w} / \mathrm{v}$ ) aqueous solution. The $\mathrm{CV}$ measurements were performed at room temperature with a conventional three electrode system connected to software controlled electrochemical work station ( $\mathrm{CH}$ Instruments 660C, USA). The working electrode was pretreated metal foil ( $\mathrm{Al}, \mathrm{Cu}, \mathrm{Pt}, \mathrm{Zn})$. In all the experiments $\mathrm{Pt}$ foil was used as auxillary electrode and SCE was used as reference electrode. CV for both blank solution $[0.2 \% \mathrm{NaCl}(\mathrm{w} / \mathrm{v})]$ and dye solution $\left(50 \mathrm{mg} \mathrm{L^{-1 }}+0.2 \%\right.$ $\mathrm{NaCl})$ were recorded and compared.

\section{Spectroscopic and chemical analysis}

To follow the degradation process, small aliquots were taken out at regular intervals, diluted with Millipore water, and UV-Visible absorbance spectrum was recorded (HR 4000 UV-Vis Spectrophotometer, UV-Vis-NIR light source, DTMINI-2-GS, Jaz detector, SP-2102 UVPC (path length=1 cm)). The percentage color removal with reference to the absorption at $\lambda_{\max }$ was calculated using eq. (1).

$$
\text { Color removal, } \%=\frac{\left[A b s_{0}-A b s_{z}\right]}{A b s_{0}} \times 100
$$

where, $\mathrm{Abs}_{0}$ and $\mathrm{Abs}_{\mathrm{t}}$ are the absorbance at $\lambda_{\max }$, at time 0 and $\mathrm{t}$ minutes of electrolysis, respectively. The mineralization of dye was monitored by the changes in $\mathrm{COD}\left(\mathrm{g}_{\mathrm{O} 2} \mathrm{~L}^{-1}\right)$ as estimated by the open reflux method. The percentage COD removal was calculated using relation (2).

$$
C O D \text { removal, } \%=\frac{\left[C O D_{0}-C O D_{t}\right]}{C O D_{0}} \times 100
$$


where, $\mathrm{COD}_{0}$ and $\mathrm{COD}_{\mathrm{t}}$ are the $\mathrm{COD}$ at time 0 and $\mathrm{t}$ minutes of electrolysis, respectively. The percentage average current efficiency (ACE) for the removal of COD was evaluated by relation (3).

$$
A C E, \%=\frac{\left[C O D_{0}-C O D_{t}\right] F V}{81 t} \times 100
$$

where $\mathrm{F}$ is the Faraday's constant $\left(96,485 \mathrm{C} \mathrm{mol}^{-1}\right), \mathrm{COD}$ in $\left(\mathrm{g}_{\mathrm{O} 2} \mathrm{~L}^{-1}\right)$, I is the current $(\mathrm{A}), \mathrm{V}$ is the volume $(\mathrm{L})$ of electrolyte, $\mathrm{t}$ - time (s), 8 - gram equivalent mass of oxygen $\left(\mathrm{g}\right.$ equiv $\left.^{-1}\right)$. The specific energy consumption per $\mathrm{kg}$ COD removal was calculated by eq. (4).

Energy consumption $k W h(k g C O D)^{-1}=\frac{I V t}{(\triangle C O D) V s}$

where $\mathrm{I}$ is the average applied current (A), V is the average cell voltage $(\mathrm{V}), \mathrm{t}$ is the electrolysis time $(\mathrm{h}), \mathrm{Vs}$ is the solution volume $(\mathrm{L}), \triangle \mathrm{COD}$ is the decay in $\operatorname{COD}\left(\mathrm{g} \mathrm{L}^{-1}\right)$.

\section{Results and discussion \\ Electrochemical studies}

The LSV was performed on each cathode material in aqueous $\mathrm{NaCl} 0.2 \%(\mathrm{w} / \mathrm{v})$ solution (Fig. 1) to know the potential for hydrogen evolution reaction (Table 2). Evidently, $\mathrm{Cu}$ exhibited the least activity for hydrogen evolution reaction, whereas on $\mathrm{Pt}$, hydrogen evolution commenced at $-0.7 \mathrm{~V}$. Further, the $\mathrm{CV}$ was recorded for each dye $\left(50 \mathrm{mg} \mathrm{L}^{-1}\right)$ in $0.2 \%(\mathrm{w} / \mathrm{v}) \mathrm{NaCl}$ solution using different cathode materials as working electrode. The operating potential window was selected for each cathode and CV scans were performed (Fig. 2).

Both MO and MG were found to be electrochemically inactive on all the cathode materials within the operating potential window; whereas peaks corresponding to oxidation and reduction of $\mathrm{MB}$ on $\mathrm{Cu}$ electrodes were observed in the potential range of -0.2 to $-0.4 \mathrm{~V}$ vs. SCE (inset).

A peak at $-1.42 \mathrm{~V}$ vs. SCE was observed in the CV obtained in blank solution on $\mathrm{Zn}$ electrode. This peak is due to the electro-reduction of $\mathrm{Zn}^{2+}$ ions liberated from the surface of $\mathrm{Zn}$ electrode dipped in $\mathrm{NaCl}$ solution. The chemical attack of $\mathrm{NaCl}$ on $\mathrm{Zn}$ electrode generates $\mathrm{Zn}^{2+}$ ions. These $\mathrm{Zn}^{2+}$ ions get reduced to $\mathrm{Zn}$ at $-1.42 \mathrm{~V}$ vs. SCE before hydrogen evolution. To elucidate the presumption of $\mathrm{Zn}^{2+}$ ion reduction to $\mathrm{Zn}$, the $\mathrm{CV}$ scans were performed in $1.0 \mathrm{mM} \mathrm{ZnSO}_{4}$ solution with $0.2 \% \mathrm{NaCl}$ as supporting electrolyte under similar conditions. A peak at $-1.41 \mathrm{~V}$ vs. SCE (Fig. 3) confirms the $\mathrm{Zn}^{2+}$ reduction. Further, to make sure that this peak is not due to oxygen reduction, a cyclic voltammogram was recorded on $\mathrm{Zn}$ electrode in aqueous $0.2 \% \mathrm{NaCl}$ solution purged with nitrogen for 30 minutes. The peak at $-1.4 \mathrm{~V}$ vs. SCE again appeared in $\mathrm{CV}$, negating the chances of $\mathrm{O}_{2}$ reduction reaction. Consequently, the formation of $\mathrm{H}_{2} \mathrm{O}_{2}$ by the reduction of $\mathrm{O}_{2}$ is ruled out in the present case. 

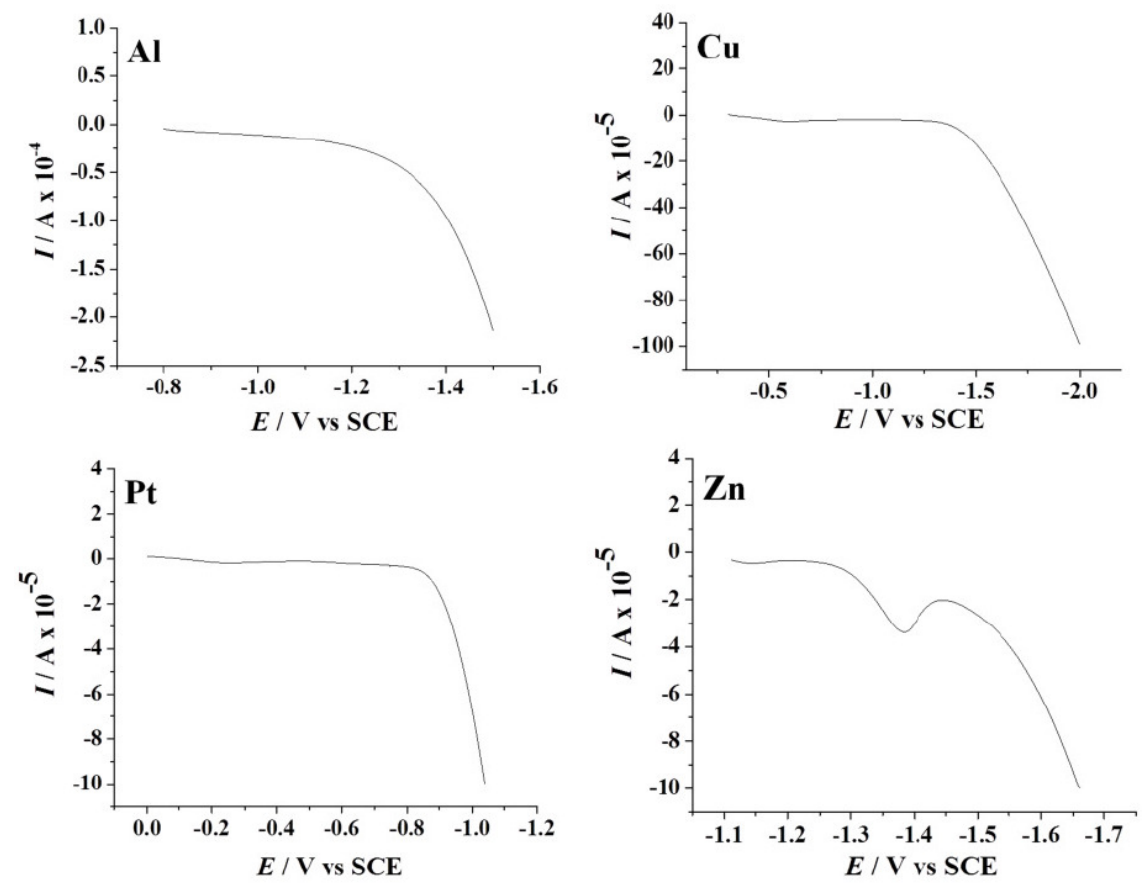

Figure 1. Linear sweep voltammogram in $0.2 \% \mathrm{NaCl}$ aqueous solution for different metals under the scan rate of $20 \mathrm{mV} \mathrm{s}^{-1}$.
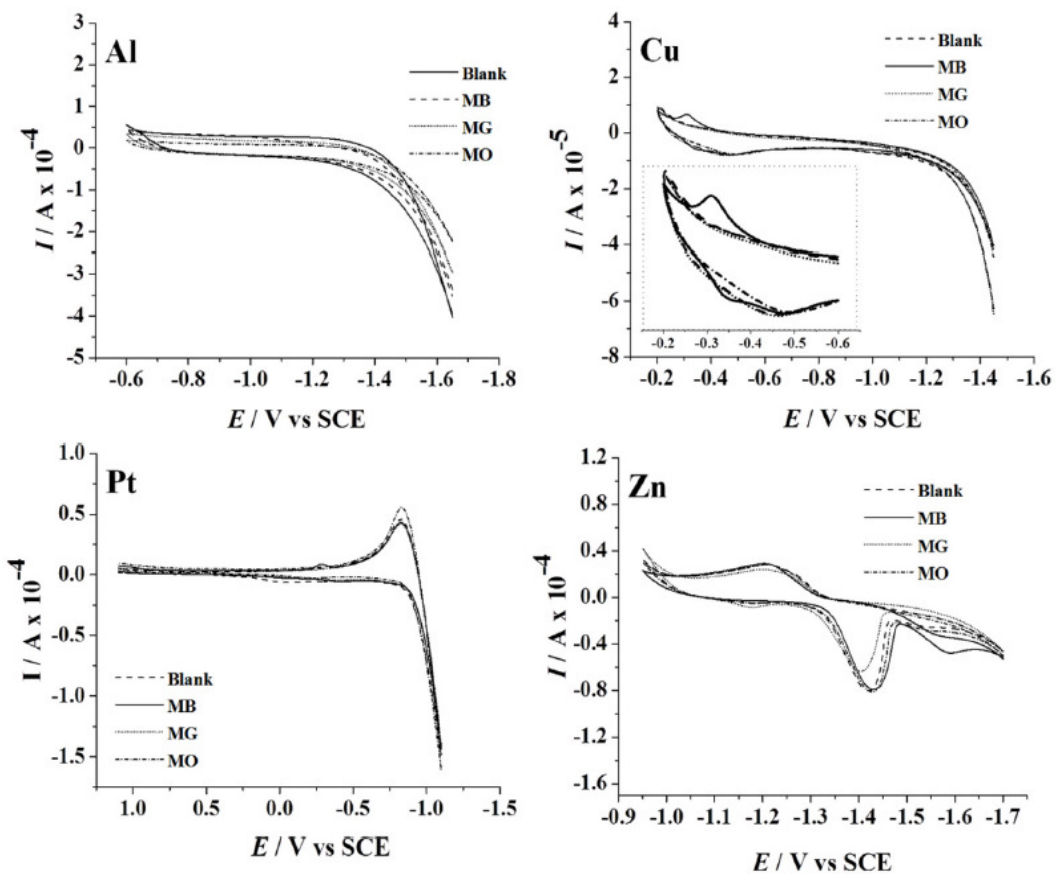

Figure 2. Cyclic voltammogram in $0.2 \% \mathrm{NaCl}$ aqueous solution without (blank) and with dye $50 \mathrm{mg} \mathrm{L}^{-1}$, scan rate $50 \mathrm{mV} \mathrm{s}^{-1}$.

Table 2. Hydrogen evolution reaction potential (HER).

\begin{tabular}{cc}
\hline Electrode & HER / V (vs. SCE) \\
\hline Copper & -1.3 \\
Zinc & -1.2 \\
Aluminum & -1.1 \\
Platinum & -0.7 \\
\hline
\end{tabular}




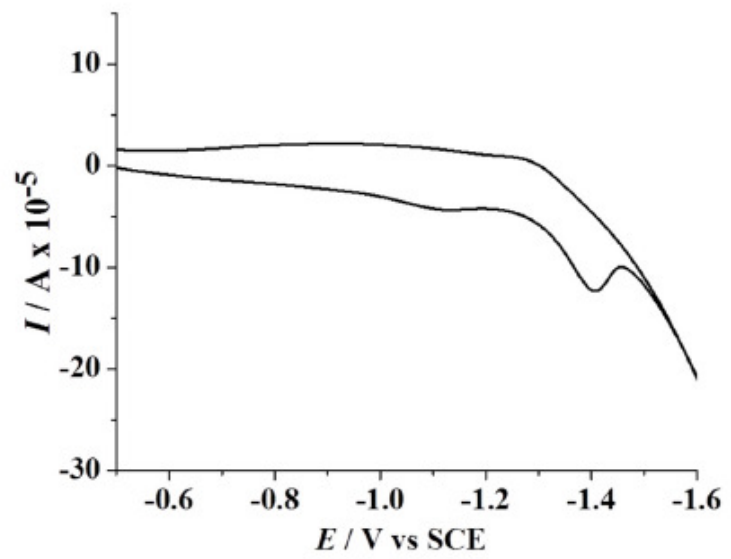

Figure 3. Cyclic voltammogram in $1.0 \mathrm{mM} \mathrm{ZnSO}_{4}$ aqueous solution with $0.2 \% \mathrm{NaCl}$ as supporting electrolyte, scan rate $100 \mathrm{mV} \mathrm{s}^{-1}$.

\section{Electrolysis in undivided cell}

Electrolysis of $0.2 \%(\mathrm{w} / \mathrm{v})$ aqueous $\mathrm{NaCl}$ solution containing $50 \mathrm{mg} \mathrm{L}^{-1}$ dye was performed for a period of 60 minutes under galvanostatic conditions $(40 \mathrm{~mA}$ $\mathrm{cm}^{-2}$ ). The progress in degradation was monitored by evaluating the changes in color (Fig. 4 and 5) and COD (Fig. 6) at regular intervals of time.
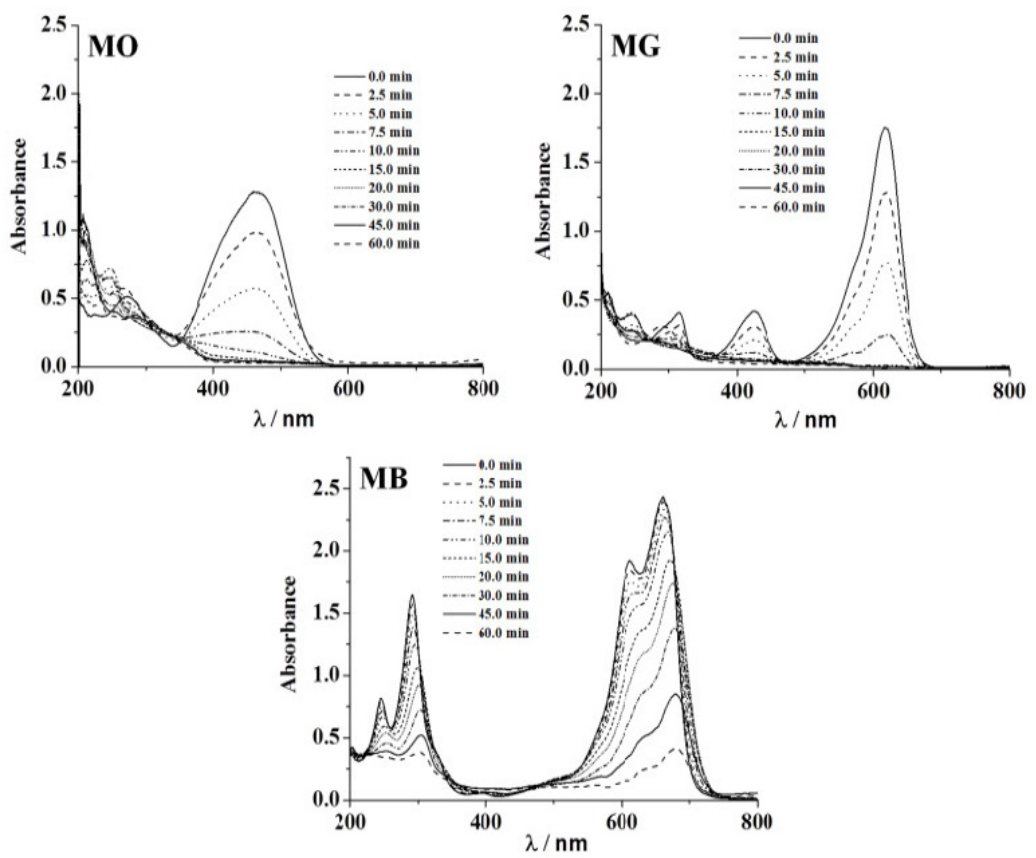

Figure 4. The UV-Visible absorption spectra with time of electrolysis using Pt anode and $\mathrm{Al}$ cathode. 


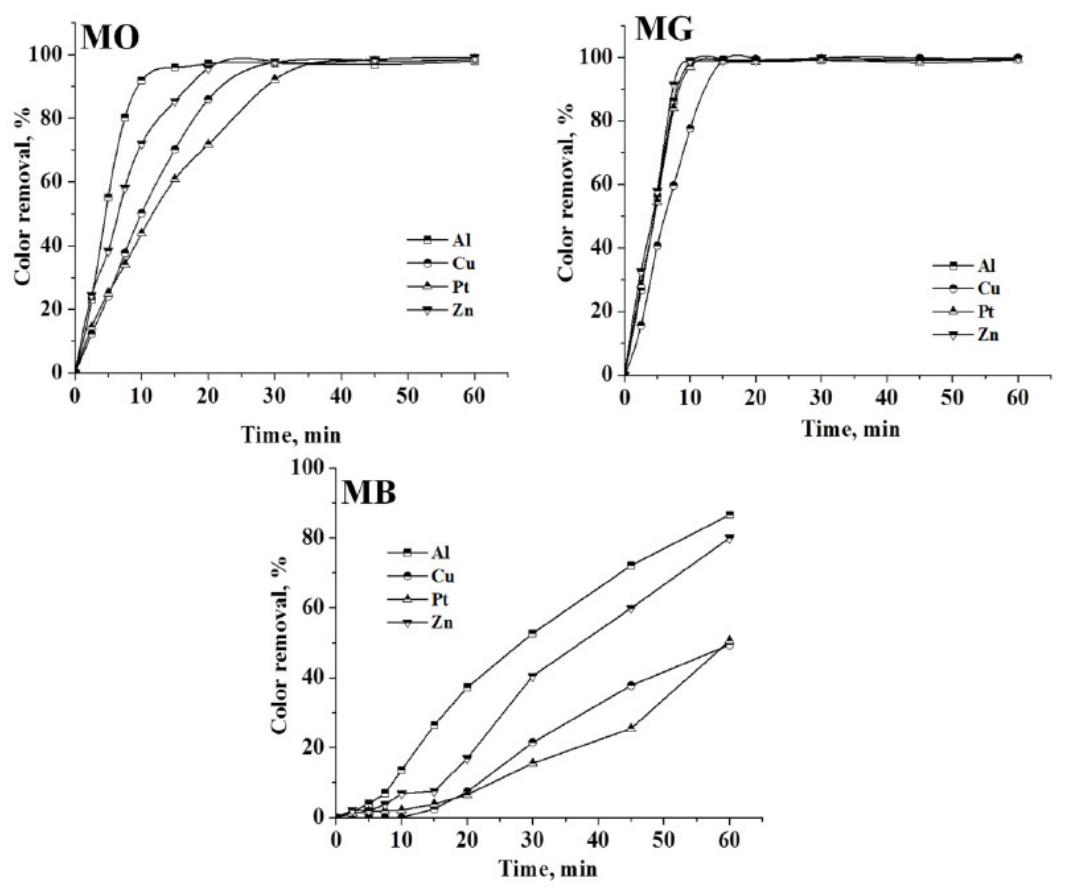

Figure 5. The percentage color removal with time of electrolysis on different cathode materials.

The peaks at $465 \mathrm{~nm}$ and $617 \mathrm{~nm}$ in the UV-Visible absorption spectrum of MO and MG slowly disappeared with time on electrolysis and complete discoloration was achieved for both $\mathrm{MO}$ and MG dyes. However, the rate of discoloration of MO was less as compared to that of MG. $98 \%$ discoloration of MO was achieved within 35-40 minutes of electrolysis, whereas $\sim 100 \%$ discoloration of MG was attained within 20 minutes. The absorption in the range of 200-300 nm in the UV-Visible spectra of MO dye remained as such even after 60 minutes of electrolysis. This can be ascribed to the aromatic compounds reluctant to oxidation prevailing in the solution. On the other hand, the MB dye was resistant to discoloration. The highest \% color removal of MB attained after 60 minutes of electrolysis was only $87 \%$ with $\mathrm{Al}$ cathode.

The trend in the COD removal was similar to that of discoloration. The percentage color and COD removal achieved after a period of 60 minutes electrolysis has been tabulated in Table 3. The COD removal of MG was faster and higher as compared to the degradation of $\mathrm{MO}$ and $\mathrm{MB}$. The average COD removal of $\mathrm{MB}$ was the least amongst the three dyes with $\mathrm{Al}$ cathode. The percentage COD removal achieved after 60 minutes of electrolysis under similar conditions followed the order: $\mathrm{MG}>\mathrm{MO}>\mathrm{MB}$. This suggests that not only the operating conditions, but also the nature of the organic molecule itself influences the degradation process. The heterocyclic aromatic structure of MB was most resistant to degradation and triphenyl methane structure of MG was most vulnerable to electrochemical oxidation. 

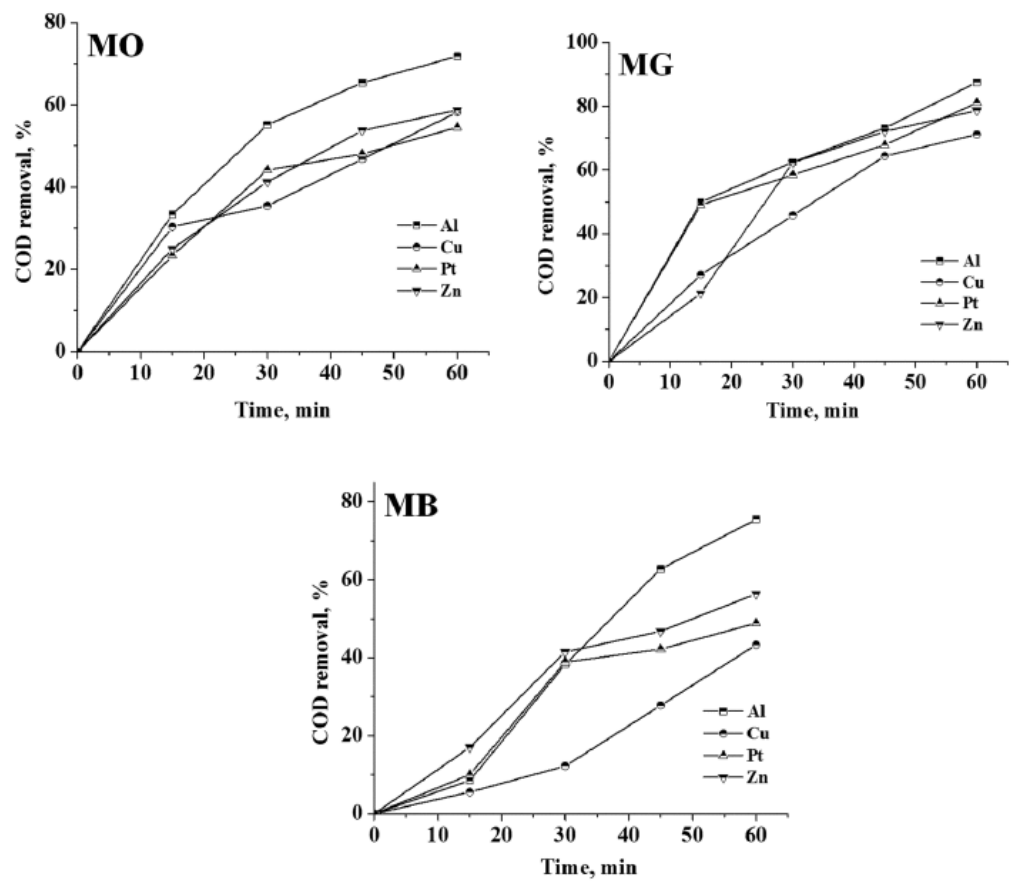

Figure 6. Percentage of COD removal with time on different cathode materials.

Table 3. Color and COD removal in an undivided cell.

\begin{tabular}{ccccccc}
\hline & \multicolumn{3}{c}{ MO } & \multicolumn{2}{c}{ MG } & \multicolumn{3}{c}{ MB } \\
\cline { 2 - 7 } Cathode & ${ }^{\mathrm{a}} \mathrm{A}$ & ${ }^{\mathrm{b}} \mathrm{B}$ & $\mathrm{A}$ & $\mathrm{B}$ & $\mathrm{A}$ & $\mathrm{B}$ \\
\hline $\mathrm{Al}$ & 98 & 72 & 100 & 88 & 87 & 76 \\
$\mathrm{Cu}$ & 98 & 58 & 100 & 71 & 49 & 43 \\
$\mathrm{Pt}$ & 99 & 56 & 99 & 81 & 51 & 49 \\
$\mathrm{Zn}$ & 99 & 59 & 100 & 79 & 80 & 56 \\
\hline \multicolumn{4}{c}{${ }^{\mathrm{a}}$ color removal, \%; ${ }^{\mathrm{b}}$ COD removal, \% }
\end{tabular}

Though, the trend in the discoloration and degradation was similar with all cathode materials used in the study, the maximum percentage color and COD removal varied with the cathode material. Both discoloration and degradation of all 3 dyes was faster with $\mathrm{Al}$ and $\mathrm{Zn}$ cathodes. This can be attributed to the fact that $\mathrm{Al}$ is chemically attacked by ${ }^{-} \mathrm{OH}$ ions generated during the electrolysis [40]. The $\mathrm{Al}^{3+}$ ions thus obtained, form soluble monomeric $\left(\mathrm{Al}(\mathrm{OH})_{\mathrm{y}}{ }^{3+}\right)$ and polymeric $\left(\mathrm{Al}_{\mathrm{x}}(\mathrm{OH})_{\mathrm{y}}{ }^{3+}\right)$ species, which later converted into insoluble flocs by the complex precipitation kinetics. These reactions are given in eqs. (5) to (10) [40]:

$$
\mathrm{Al}+3 \mathrm{H}_{2} \mathrm{O}+{ }^{-} \mathrm{OH} \rightarrow \mathrm{Al}(\mathrm{OH})_{4}{ }^{-}+3 / 2\left(\mathrm{H}_{2}\right)
$$

The dye molecule complexes with the Al cationic species and the interaction between them leads to the formation of precipitate. The neutralization of charges leads to the formation of precipitate at $\mathrm{pH}<5$, and adsorption on $\mathrm{Al}(\mathrm{OH})_{3}$ flocs followed by coagulation to form particles occurs at $\mathrm{pH}>6.5$ [40]: 


$$
\begin{array}{ll}
\text { Dye- } \mathrm{H}+(\mathrm{HO}) \mathrm{OAl}_{(\mathrm{s})} \rightarrow \text { Dye-OAl }_{(\mathrm{s})}+\mathrm{H}_{2} \mathrm{O} & \\
\text { Dye }+ \text { monomeric } \mathrm{Al} \rightarrow[\text { Dye-monomeric } \mathrm{Al}]_{(\mathrm{s})} & \mathrm{pH}<5.0 \\
\text { Dye }+ \text { polymeric } \mathrm{Al} \rightarrow[\text { Dye-polymeric } \mathrm{Al}]_{(\mathrm{s})} & \mathrm{pH}<5.0-6.0 \\
\text { Dye }+\mathrm{Al}(\mathrm{OH})_{3(\mathrm{~s})} \rightarrow[\text { Particle }] & \mathrm{pH}>6.5 \\
{[\text { Dye-polymeric } \mathrm{Al}]_{(\mathrm{s})}+\mathrm{Al}(\mathrm{OH})_{3(\mathrm{~s})} \rightarrow[\text { Particle }]} &
\end{array}
$$

The large surface area of $\mathrm{Al}(\mathrm{OH})_{3(\mathrm{~s})}$ flocs adsorbs soluble organic compounds $[36,40]$. On electrolysis for 60 minutes, the $\mathrm{pH}$ of the solution was $>7.8$ for all dyes. Under these conditions the reactions in eqs. 9 and 10 are favorable. As a result, the formation of froth and particulates is expected and the same was observed during the electrolysis. Also, the hydrogen evolution and dissolution of cathode material were noticed. The dissolution of $\mathrm{Zn}$ metal into $\mathrm{Zn}^{2+}$ ions in $\mathrm{NaCl}$ solution is evident by the $\mathrm{CV}$ studies, and very low concentration of $\mathrm{Zn}^{2+}$ ions in the test solution is expected.

It is known that at low zinc concentrations, the $\mathrm{Zn}^{2+}$ ion dominates up to $\mathrm{pH} 8.7$, while $\mathrm{Zn}(\mathrm{OH})_{2}$ is the dominant species between $\mathrm{pH} 8.7$ and 11.4. This $\mathrm{Zn}(\mathrm{OH})_{2}$ acts as adsorbent for the adsorption of dye molecules. The following reactions are expected.

$$
\begin{aligned}
& \mathrm{Zn}+\mathrm{H}_{2} \mathrm{O}+{ }^{-} \mathrm{OH} \rightarrow \mathrm{Zn}(\mathrm{OH})_{2(\mathrm{~s})}+1 / 2 \mathrm{H}_{2} \\
& \text { Dye }+\mathrm{Zn}(\mathrm{OH})_{2(\mathrm{~s})} \rightarrow[\text { Particle }]
\end{aligned}
$$

It was established that during electrolysis of aqueous solutions using $\mathrm{NaCl}, \mathrm{HOCl}$ predominates in the $\mathrm{pH}$ range 3-8, and in $\mathrm{pH}>8,{ }^{-} \mathrm{OCl}$ is the dominant species (Eq. 13-16) [41, 42]. $\mathrm{HOCl}$ with higher standard reduction potential is a strong oxidizing agent $[40,43]$. In the present case, the $\mathrm{pH}$ of dye solution lies in the range where both electro-flocculation and formation of oxidizing agents are favored. The combined effect of oxidation brought about by the active chlorine species $\mathrm{HOCl}, \mathrm{Cl}_{2},{ }^{-} \mathrm{OCl}$ and the electro-floccuation, resulted in higher $\mathrm{COD}$ removal with $\mathrm{Al}$ and $\mathrm{Zn}$ cathodes.

$$
\begin{aligned}
& 2 \mathrm{Cl}^{-} \rightarrow \mathrm{Cl}_{2(\mathrm{aq})}+2 \mathrm{e}^{-} \quad\left(\text { Standard potential of } \mathrm{Cl}_{2}\left(\mathrm{E}^{\mathrm{o}}\right)=1.40 \mathrm{~V} \text { vs. SHE }\right) \\
& \mathrm{Cl}_{2(\mathrm{aq})}+\mathrm{H}_{2} \mathrm{O} \rightarrow \mathrm{HOCl}+\mathrm{H}^{+}+\mathrm{Cl}^{-} \quad\left(\mathrm{E}^{\mathrm{o}} \text { of } \mathrm{HOCl}=1.49 \mathrm{~V} \text { vs. SHE }\right) \\
& \mathrm{HOCl} \leftrightarrow \mathrm{H}^{+}+\mathrm{OCl}^{-} \quad(\mathrm{pH} 3-8 \leftrightarrow \mathrm{pH}>8) \quad\left(\mathrm{E}^{\mathrm{o}} \text { of } \mathrm{ClO}^{-}=0.89 \mathrm{~V} \text { vs. SHE }\right) \\
& \text { Dye }+\mathrm{OCl}^{-} \rightarrow \text { Intermediates } \rightarrow \mathrm{CO}_{2}+\mathrm{H}_{2} \mathrm{O}+\mathrm{Cl}^{-}
\end{aligned}
$$

\section{Degradation in a divided cell}

To determine the effect of cathode material and cathodic reactions on the degradation of dyes by indirect electro-oxidation process, experiments were conducted in a divided cell. 
The progress in color and COD removal (Fig. 7 - 9) in the anode compartment was monitored and these data are summarized in Table 4. Complete discoloration of both MO and MG was achieved in the anode compartment of the divided cell. For $\mathrm{MB}$, the discoloration was above $90 \%$ with all cathodes. The $\%$ COD removal was in the order $\mathrm{MG}>\mathrm{MO}>\mathrm{MB}$. Small \% color and COD removal was noticed in the cathode compartment. The color removal observed for $\mathrm{MB}$ solution in the cathode compartment was approximately $15 \%$ and there was no considerable change in its COD with all 4 cathode materials $(<10 \%)$. For MO, the color and COD removal achieved in the cathode compartment was approximately $12 \%$ and $8 \%$ respectively, irrespective of the cathode material. The \% COD removal realized for MG was between 20 and $25 \%$. These changes in color and COD removal in the cathode compartment of the divided cell can be attributed to the adsorption and / or direct electro-reduction of dyes on the electrode surface.

The changes in the UV-Visible spectrum of MB dye during the electrolysis were similar in both undivided and anode compartment of divided cell. However for MO and MG, the UV-Visible absorption spectra exhibited significant differences in divided and undivided cell systems. Three characteristic peaks in the UVVisible spectrum of MG gradually diminished on electrolysis in the undivided cell, whereas for the solution in the anode compartment of divided cell a new peak around $469 \mathrm{~nm}$ was observed. The green solution of MG dye turned yellow after 15 minutes of electrolysis and became colorless at 60 minutes of electrolysis. The MO dye showed a peak at $465 \mathrm{~nm}$ for both solutions of undivided and anode compartment of divided cell. During electrolysis, the solution of anode compartment of divided cell exhibited red shift to $500 \mathrm{~nm}$ at the beginning of electrolysis and its intensity decreased to zero by the end of the experiment. In the undivided cell, no such shift was noticed but the intensity of the peak gradually reduced to zero at $465 \mathrm{~nm}$.

One of the important observations made is that the $\mathrm{pH}$ of the test solution of electrolysis changes during the passage of time in all experiments. In the case of the undivided cell, the $\mathrm{pH}$ of the test solution increased on electrolysis irrespective of the dye solution. However, in the divided cell there was rise in $\mathrm{pH}$ in the cathode compartment and fall in $\mathrm{pH}$ of anode compartment. The $\mathrm{pH}$ changes observed on electrolysis in the divided and undivided cell systems have been given in Table 5 .

As mentioned earlier, the acidic condition encourages the subsistence of in-situ generated $\mathrm{HOCl}$ which oxidized the dyes, resulting in the color and COD removal. As a result, the percentage of discoloration and degradation achieved in the anode compartment was higher than that observed in the undivided cell. 

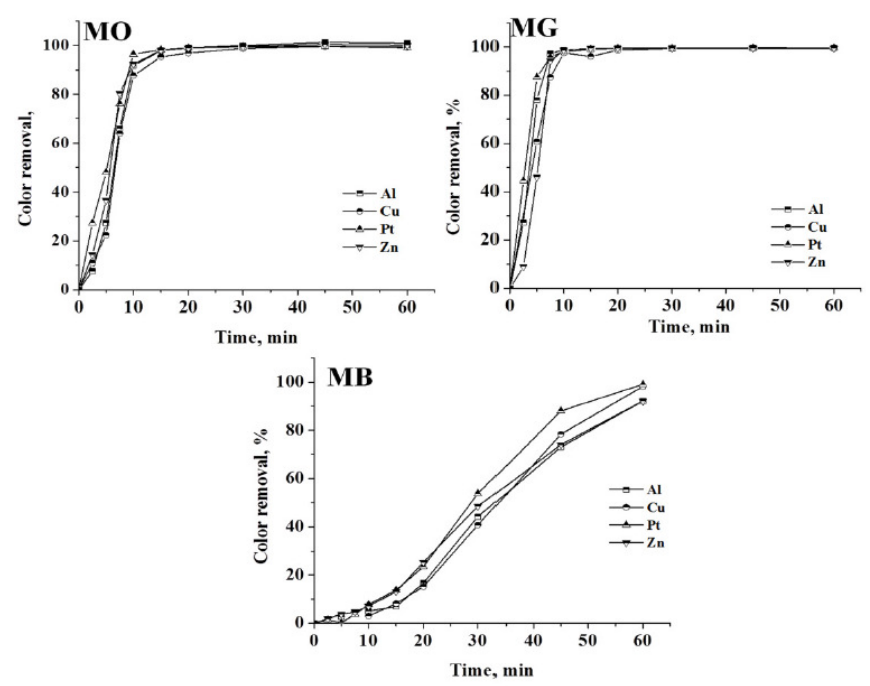

Figure 7. Percentage of color removal in the anode compartment of the divided cell.
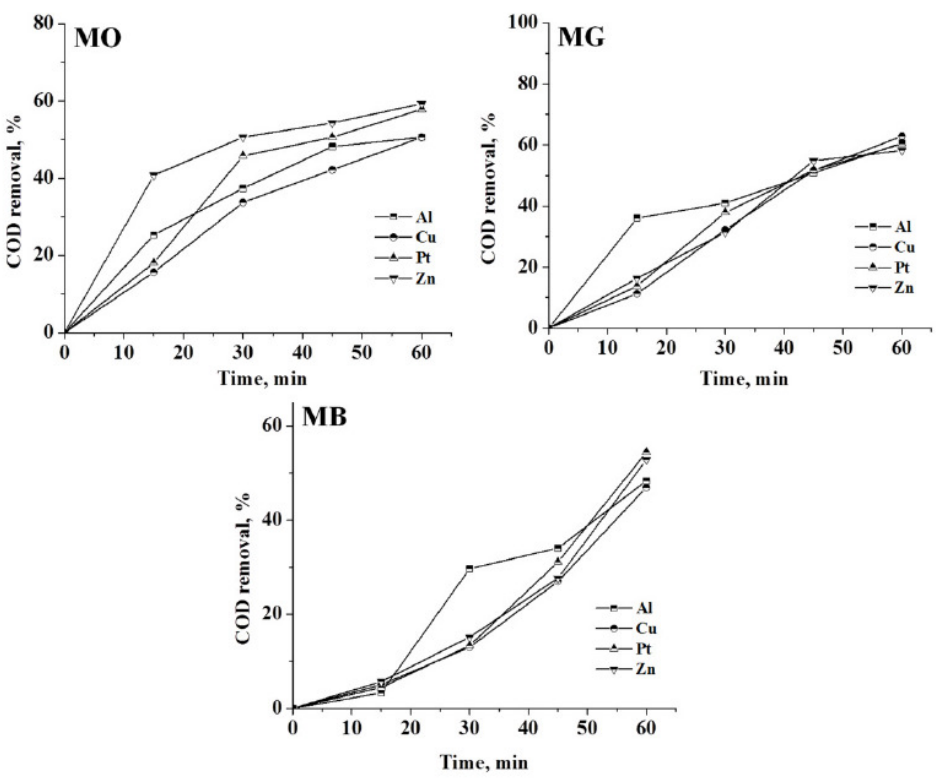

Figure 8. Percentage of color removal in the anode compartment of the divided cell system.
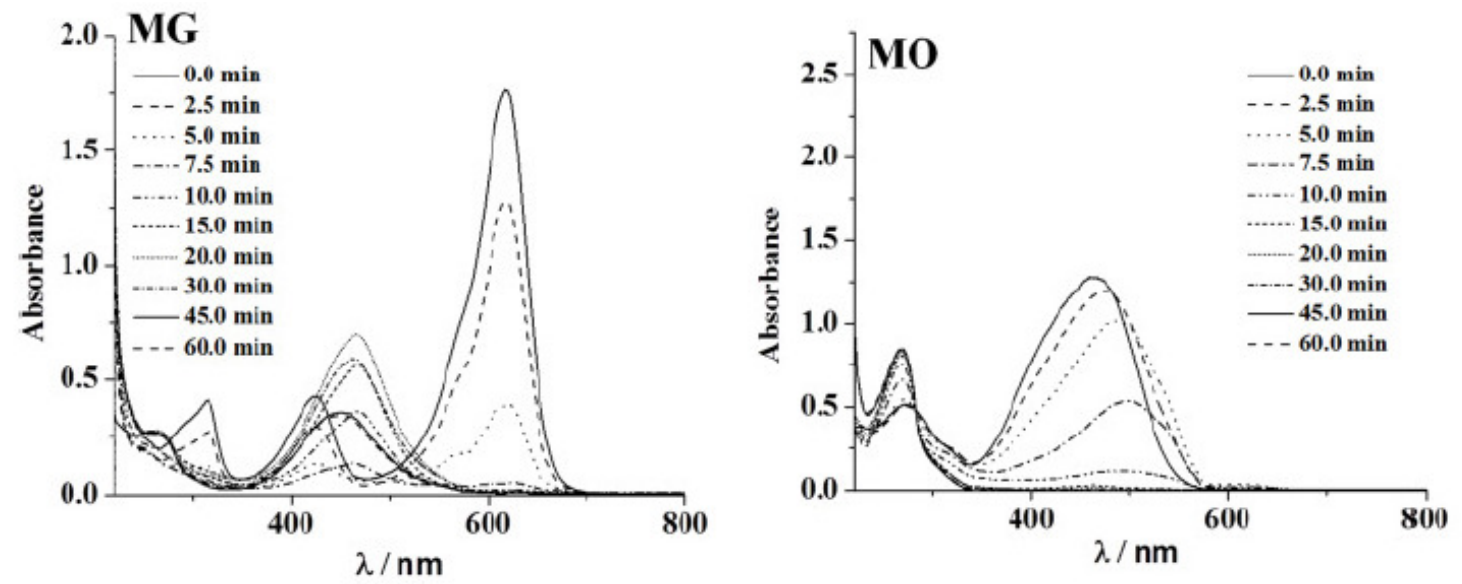

Figure 9. UV-Visible absorption spectrum of $\mathrm{MG}$ and $\mathrm{MO}$ dyes in the anode compartment of the divided cell. 
Table 4: Color and COD removal in a divided cell.

\begin{tabular}{|c|c|c|c|c|c|c|}
\hline \multirow[b]{2}{*}{ Cathode } & \multicolumn{2}{|c|}{ MO } & \multicolumn{2}{|c|}{ MG } & \multicolumn{2}{|c|}{ MB } \\
\hline & ${ }^{\mathrm{a}} \mathrm{A}$ & ${ }^{b} \mathrm{~B}$ & A & B & $\mathrm{A}$ & B \\
\hline $\mathrm{Al}$ & 100 & 51 & 100 & 61 & 92 & 48 \\
\hline $\mathrm{Cu}$ & 99 & 51 & 99 & 63 & 98 & 47 \\
\hline $\mathrm{Pt}$ & 99 & 58 & 100 & 60 & 99 & 54 \\
\hline $\mathrm{Zn}$ & 100 & 60 & 100 & 58 & 92 & 53 \\
\hline
\end{tabular}

The color of $\mathrm{MO}$ and $\mathrm{MG}$ dyes are $\mathrm{pH}$ sensitive. The $\mathrm{MO}$ dye is yellow above $\mathrm{pH} 4.4$ and turns red in $\mathrm{pH}<4.4$. The $\mathrm{pH}$ of as prepared MO solution was 6.2, which increased to 11.8 in the cathode compartment on electrolysis for 60 minutes. In the anode compartment, the MO solution turned red due to reduction in $\mathrm{pH}$ which is $<4.4$ after electrolysis. The red shift in the UV-Visible absorption at $465 \mathrm{~nm}$ is due to this $\mathrm{pH}$ change. The discoloration of red solution of MO dye in anode solution was brought about by the in-situ generated active chlorine species. However, the MO dye solution in the cathode compartment did not show any change in the absorption intensity. This is because the $\mathrm{pH}$ of cathode compartment turned basic on electrolysis. The MO dye solution is yellow in basic $\mathrm{pH}$ and persisted throughout the experiment.

Table 5. $\mathrm{pH}$ of dye solutions before and after electrolysis.

\begin{tabular}{ccc|cc}
\hline \multirow{2}{*}{} & \multirow{2}{*}{ Undivided cell } & \multicolumn{3}{c}{ Divided cell } \\
\cline { 4 - 5 } Dye & Initial & Final & Anode compartment & Cathode compartment \\
\cline { 2 - 5 } MO & 6.2 & 8.4 & 2.2 & Final \\
MG & 4.0 & 7.9 & 2.1 & 11.8 \\
MB & 5.2 & 9.0 & 2.2 & 12.1 \\
\hline
\end{tabular}

In case of $\mathrm{MG}$, at the end of the experiment, the solution $\mathrm{pH}$ of the anode and the cathode compartment were 2.2 and 12.1, respectively. It was noticed that the $\mathrm{pH}$ of MG dye solution when varied, imparts green color to the solution in the $\mathrm{pH}$ range 1.8 to 11.4 . Below $\mathrm{pH} 1.8$ the color of $\mathrm{MG}$ dye solution was yellow and this color remains but in $\mathrm{pH}$ above 11.8 it is colorless. After the electrolysis, the anode compartment solution $\mathrm{pH}$ was 2.2. Therefore, the yellow color of MG was not due to the $\mathrm{pH}$ change but due to the intermediate compounds generated by the indirect electro-oxidation of MG. The peak at $256 \mathrm{~nm}$ corresponding to the aromatic structure, regularly diminished and reached a minimum. The color removal was due to the oxidative degradation brought about by the active chlorine species. On the contrary, the intense green color of MG solution in the cathode compartment slowly faded and became colorless on electrolysis with time. 


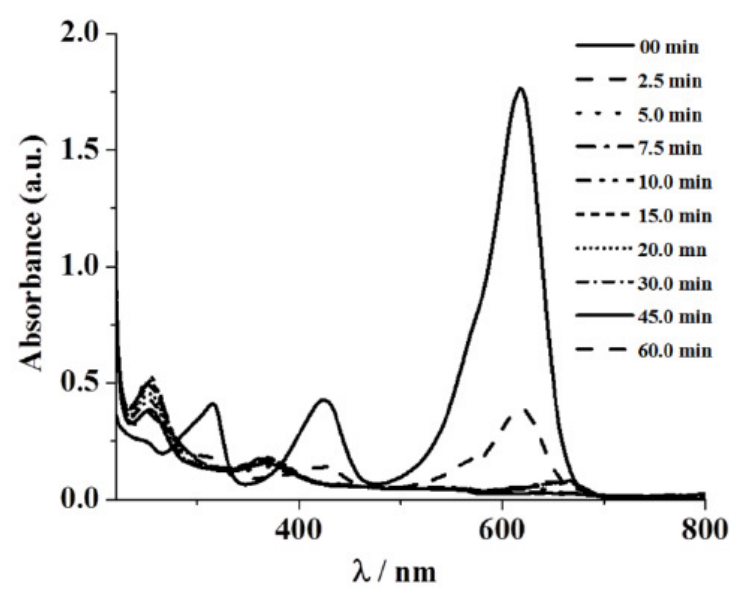

Figure 10. UV-Visible absorption spectrum of MG dye in the cathode compartment of the divided cell.

This change in color was due to $\mathrm{pH}$ change occurred in cathode compartment. The conjugation in the MG structure is lost due to the formation of triphenylcarbinol structure by basic hydrolysis of MG (eq. 17) [40, 44, 45]. The absorbance observed in the UV-Visible spectrum at $256 \mathrm{~nm}$ of the cathode compartment can be attributed to this structure, which persisted even after electrolysis for $60 \mathrm{~min}$ (Fig. 10).

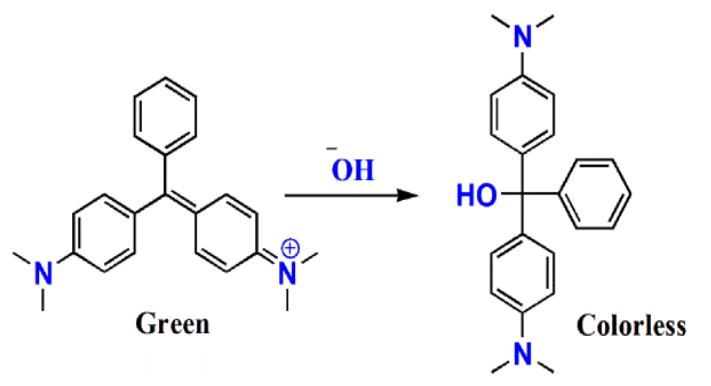

The COD removal for a particular dye solution in the anode compartment of the divided cell was almost the same irrespective of the cathode material used. This is because the degradation was brought about only by the in-situ generated active chlorine species and the concentration of the active chlorine species generated for a particular current density was the same. From the COD removal data given in Tables 3 and 5, the overall degradation achieved in the undivided cell system and in the anode compartment of the divided cell system is comparable.

\section{Energy consumption and efficiency}

The specific energy consumption and the average current efficiency for maximum COD removal in 60 minutes of electrolysis was calculated for both undivided and divided systems and presented in Table 6.

In general, the performance of Al-Pt and $\mathrm{Zn}$-Pt (cathode - anode) pairs was found to be the highest as compared to $\mathrm{Cu}-\mathrm{Pt}$ and $\mathrm{Pt}-\mathrm{Pt}$ pairs. As evident from the data, the electrolytic system with $\mathrm{Al}$ and $\mathrm{Zn}$ cathodes showed the highest efficiency of COD removal with low energy consumption. 
Table 6. Specific energy consumption and average current efficiency (ACE) for COD removal using the undivided cell.

\begin{tabular}{ccccccc}
\hline & \multicolumn{2}{c}{ MO } & \multicolumn{2}{c}{ MG } & \multicolumn{2}{c}{ MB } \\
\cline { 2 - 7 } Cathode & ${ }^{\mathrm{a}} \mathrm{A}$ & ${ }^{\mathrm{b}} \mathrm{B}$ & $\mathrm{A}$ & $\mathrm{B}$ & $\mathrm{A}$ & $\mathrm{B}$ \\
\hline $\mathrm{Al}$ & 30 & 274 & 27 & 313 & 38 & 216 \\
$\mathrm{Cu}$ & 25 & 367 & 23 & 402 & 31 & 433 \\
$\mathrm{Pt}$ & 24 & 400 & 24 & 391 & 24 & 389 \\
$\mathrm{Zn}$ & 25 & 3845 & 26 & 338 & 29 & 306 \\
\hline${ }^{\mathrm{a}}$ ACE, \%; & &
\end{tabular}

The performance of electrolytic cell system with $\mathrm{Cu}$ and $\mathrm{Pt}$ cathodes was just satisfactory. The MG dye consumed the highest specific energy for the degradation. Although the MG dye color removal was faster than the other two dyes, the degradation of the dye consumed more energy. This can be ascribed to the resistance offered by the intermediates generated by the oxidation of MG. The energy required to reduce the COD to a particular level in the degradation of $\mathrm{MG}$ dye was more than that required to reduce the COD to the same level in case of $\mathrm{MO}$ and $\mathrm{MB}$.

\section{Conclusion}

The degradation of MG, MO and MB was conducted in undivided and divided cell systems with different cathode materials. The in-situ generated active chlorine species brought about the degradation of organics. The performance of $\mathrm{Al}$ and $\mathrm{Zn}$ metals as cathode materials was found to be higher than that of $\mathrm{Cu}$ and $\mathrm{Pt}$ as cathodes in this process. The changes in the $\mathrm{pH}$ of the wastewater matrix influenced the color and COD removal in divided and undivided cell systems. The basic $\mathrm{pH}$ attained on electrolysis and aqueous chloride solution chemically attacked the $\mathrm{Al}$ and $\mathrm{Zn}$ cathodes, which led to the formation of flocs. This resulted in the higher percentage color and COD removal with $\mathrm{Al}$ and $\mathrm{Zn}$ cathodes in the undivided cell system. The decoloration and degradation in the anode compartment of the divided cell was comparable with the undivided cell; however, the COD removal achieved for each dye was almost the same with all the cathode materials. The higher acidic $\mathrm{pH}$ in the divided cell led to the faster color and COD removal in the anode compartment of the divided cell. The $\mathrm{pH}$ variation in the undivided cell was just satisfactory to sustain highly reactive active chlorine species and the formation of flocs, which led to higher color and $\mathrm{COD}$ removal with $\mathrm{Al}$ and $\mathrm{Zn}$ cathodes, whereas $\mathrm{Cu}$ and $\mathrm{Pt}$ resistant to chemical reaction with ${ }^{-} \mathrm{OH}$ and chloride media produced no flocs and hence the showed reduced performance, as is evident from the calculated current efficiency and energy consumption data. Complete discoloration of $\mathrm{MG}$ and $\mathrm{MO}$ was successfully achieved in all cases. The MB dye showed highest resistance to both decoloration and degradation. This indicates that not only the operating 
conditions but the cathode material and also the property of dye itself affect the color and COD removal of wastewater containing these dyes.

\section{Acknowledgements}

Authors thank the University Grants Commission, New Delhi (Ref: F. No. 41-231/2012 (SR) Dated 16/07/2012) Govt. of India for providing financial assistance to carry out this work, and Department of chemistry, Kuvempu University for providing laboratory facilities.

\section{References}

1. Cheng W, Wang SG, Lua L, et al. Removal of malachite green (MG) from aqueous solutions by native and heat-treated anaerobic granular sludge. Biochem Eng Jour. 2008;39:538-546.

2. Kalyani DC, Telke AA, Surwase SN, et al. Effectual decolorization and detoxification of triphenylmethane dye malachite green (MG) by Pseudomonas aeruginosa NCIM 2074 and its enzyme system. Clean Techn Environ Policy. 2012;14:989-1001.

3. Murugesan K, Yang IH, Kim YM, et al. Enhanced transformation of malachite green by laccase of ganoderma lucidum in the presence of natural phenolic compounds. Appl Microbiol Biotechnol. 2009;82:341-350.

4. Soloman PA, Basha CA, Velan M, et al. Electro oxidation of malachite green and modeling using ANN. Chem Biochem Eng Q. 2010;24:445-452.

5. Soni A, Tiwari A, Bajpai AK. Removal of malachite green from aqueous solution using nano-iron oxide-loaded alginate microspheres: batch and column studies. Res Chem Intermed. 2014;40:913-930.

6. Daneshvar N, Ayazloo M, Khataee AR, et al. Biological decolorization of dye solution containing malachite green by microalgae cosmarium sp. Biores Technol. 2007;98:1176-1182.

7. Henderson AL, Schmitt TC, Heinze TM, et al. Reduction of malachite green to leucomalachite green by intestinal bacteria. App Environ Microbio. 1997;63:4099-4101.

8. Hernández-Torres ME, Ojeda-Carrera MT, Sánchez-Cantú M, et al. $\mathrm{CdS} / \mathrm{TiO}_{2}$ composite films for methylene blue photodecomposition under visible light irradiation and non-photocorrosion of cadmium sulfide. Chemical Papers. 2014;68:1257-1264.

9. El Hajj Hassan MA, El Jamal MM. Kinetic study of the electrochemical oxidation of methylene blue with Pt electrode. Port Electrochim Acta. 2012;30:351-35.

10. Han TH, Khan MM, Kalathil S, et al. Simultaneous enhancement of methylene blue degradation and power generation in a microbial fuel cell by gold nanoparticles. Ind Eng Chem Res. 2013;52:8174-8181.

11. Wang Q, Tian S, Ning P. Degradation mechanism of methylene blue in a heterogeneous Fenton-like reaction Catalyzed by Ferrocene. Ind Eng Chem Res. 2014;53:643-649. 
12. Toxicity profile for methyl orange, Bibra toxicology advice and consulting (1992), http://www.bibra-information.co.uk/profile-55.html. Accessed Jan 2014.

13. El-Sharkawy EA, Soliman AY, Al-Amer KM. Comparative study for the removal of methylene blue via adsorption and photocatalytic degradation. $\mathbf{J}$ Colloid Interf Sci. 2007;310:498-508.

14. Rajeshkannan R, Rajamohan, Rajasimman M. Removal of malachite green from aqueous solution by sorption on hydrilla verticillata biomass using response surface methodology. Front Chem Eng China. 2009;3:146-154.

15. Ru J, Hua-yue Z, Guang-ming Z, et al. Synergy of adsorption and visible light photocatalysis to decolor methyl orange by activated carbon/nanosized CdS/chitosan composite. J Cent South Univ Technol. 2010;17:1223-1229

16. Vecitis CD, Gao G, Liu H. Electrochemical Carbon Nanotube Filter for Adsorption, Desorption, and Oxidation of Aqueous Dyes and Anions. J Phys Chem C. 2011;115:3621-3629.

17. Deng D, Guo J, Zeng G, et al. Decolorization of anthraquinone, triphenylmethane and azo dyes by a new isolated Bacillus cereus strain DC1. Int Biodeter Biodegrad. 2008;62:263-269.

18. Noraini CHC, Morad N, Norli I, et al. Methylene blue degradation by sphingomonas paucimobilis under aerobic conditions. Water Air Soil Pollut. 2012;223:5131-5142.

19. Ameen S, Akhtar MS, Kim YS, et al. Synthesis and characterization of novel poly(1-naphthylamine)/zinc oxide nanocomposites: Application in catalytic degradation of methylene blue dye. Colloid Polym Sci. 2010;288:1633-1638.

20. Juan Y, Jun D, Cai ZJ, et al. Mechanism of photocatalytic degradation of dye MG by TiO2-film electrode with cathodic bias potential. Chin Sci Bull, Phys Chem. 2010;55:131-139.

21. Lei J, Li X, Li W, et al. Photocatalytic degradation of methyl orange on arrayed porous iron-doped anatase $\mathrm{TiO}_{2}$. J Solid State Electrochem. 2012;16:625-632.

22. Shen J, Wu YN, Fu L, et al. Preparation of doped $\mathrm{TiO}_{2}$ nanofiber membranes through electrospinning and their application for photocatalytic degradation of malachite green. J Mater Sci. 2014;49:2303-2314.

23. $\mathrm{Xu} \mathrm{S}$, Zhu Y, Jiang $\mathrm{L}$, et al. Visible Light Induced Photocatalytic Degradation of Methyl Orange by Polythiophene/TiO ${ }_{2}$ Composite Particles. Water Air Soil Pollut. 2010;213:151-159.

24. da Silva MR, Antonia LHD, Scalvi LVA, et al. Deposition and characterization of BiVO4 thin films and evaluation as photoanodes for methylene blue degradation. J Solid State Electrochem. 2012;16:32673274.

25. Panizza M, Barbucci A, Ricotti R, et al. Electrochemical degradation of methylene blue. Sep Purif Technol. 2007;54:382-387.

26. Singh S, Srivastava VC, Mall ID. Mechanism of Dye Degradation during Electrochemical Treatment. J Phys Chem C. 2010;117:15229-15240. 
27. Fourcade F, Delawarde M, Guihard L, et al. Electrochemical Reduction Prior to Electro-Fenton Oxidation of Azo Dyes: Impact of the Pretreatment on Biodegradability. Water Air Soil Pollut. 2013;224:1385.

28. Liu RH, Sheng GP, Sun M, et al. Enhanced reductive degradation of methyl orange in a microbial fuel cell through cathode modification with redox mediators. Appl Microbiol Biotechnol. 2011;89:201-208.

29. Yahiaoui I, Aissani-Benissad F, Madi K, et al. Electrochemical PreTreatment Combined with Biological Treatment for the Degradation of Methylene Blue Dye: $\mathrm{Pb} / \mathrm{PbO} 2$ Electrode and Modeling-Optimization through Central Composite Design. Ind Eng Chem Res. 2013;52:14743-14751.

30. Valatka E, Kulèšius. $\mathrm{TiO}_{2}$-mediated photoelectrochemical decoloration of methylene blue in the presence of peroxidisulfate. J App Electrochem. 2007;37:415-420.

31. Zhao Q, Li X, Wang N, et al. Facile fabrication, characterization, and enhanced photoelectrocatalytic degradation performance of highly oriented $\mathrm{TiO}_{2}$ nanotube arrays. J Nanopart Res. 2009;11:2153-2162.

32. Zhou Z, Zhu L, Li J, et al. Electrochemical preparation of $\mathrm{TiO} 2 / \mathrm{SiO} 2$ composite film and its high activity toward the photoelectrocatalytic degradation of methyl orange. J Appl Electrochem. 2009;39:1745-1753.

33. Brillas E, Cabot P, Casado J. Electrochemical Methods for Degradation of Organic Pollutants in Aqueous Media. In: Matthew AT (ed). Chemical degradation methods for wastes and pollutants, Environmental and industrial applications. New York, USA;2013. pp 210-273.

34. Minero C, Lucchiari M, Evione D, et al. Fe(III)-enhanced sonochemical degradation of methylene blue in aqueous solution. Environ Sci Technol. 2005;39:8936-8942.

35. Yang $\mathrm{S}, \mathrm{He} \mathrm{H}, \mathrm{Wu} \mathrm{D}$, et al. Degradation of methylene blue by heterogeneous Fenton reaction using titanomagnetite at neutral $\mathrm{pH}$ values: process and affecting factors. Ind Eng Chem Res. 2009;48:9915-9921.

36. Zhemin S, Wenhua W, Jinping J, et al. Degradation of dye solution by an activated carbon fiber electrode electrolysis system. J Hazar Mater B. 2001;84:107-116.

37. Li F, Yanwei Z, Weishen Y, et al. Electrochemical degradation of amaranth aqueous solution on ACF. J Hazar Mater B. 2006;137:1182-1188.

38. Li F, Yanwei Z, Weishen Y, et al. Electrochemical degradation of aqueous solution of Amaranth azo dye on ACF under potentiostatic model. Dyes and Pigments. 2008;76:440-446.

39. Wang H, Wang JL. The cooperative electrochemical oxidation of chlorophenols in anode-cathode compartments. J Hazar Mater 154 (2008) 44-50.

40. Martínez-Huitle CA, Brillas E. Decontamination of wastewaters containing synthetic organic dyes by electrochemical methods: a general review. Appl Catal B Environ. 2009;87:105-145. 
41. Fornazari ALT, Malpass GRP, Miwa DW, et al. Application of Electrochemical Degradation of Wastewater Composed of Mixtures of Phenol-Formaldehyde. Water, Air, Soil Pollut. 2012;223:4895-4904.

42. Malpass GRP., Miwa DW, Santos RL, et al. Unexpected toxicity decrease during photoelectrochemical degradation of atrazine with $\mathrm{NaCl}$. Environ Chem Lett. 2012;10:177-182.

43. Song S, Fan J, He Z, et al. Electrochemical degradation of azo dye C.I. Reactive Red 195 by anodic oxidation on Ti/SnO2-Sb/PbO2 electrodes. Electrochim Acta. 2010;55:3606-3613.

44. Samiey B, Toosi AR. Kinetics study of malachite green fading in the presence of TX-100, DTAB and SDS. Bull Korean Chem Soc. 2009;30: 2051.

45. Soriyan O, Owoyomi O, Ogunniyi A. The Basic Hydrolysis of Malachite Green in $\beta$-Cyclodextrin/Cetyltrimethlammonium Bromide (CTAB) Mixed System. Acta Chim Slov. 2008;55:613-616. 